\title{
STRATEGI PENGELOLAAN ZAKAT DALAM UPAYA PENGEMBANGKAN USAHA PRODUKTIF (Studi Kasus Pada BAZNAS Kabupaten Bungo)
}

\author{
Muklisin \\ Fakultas Ekonomi Syariah STAI YASNI MUARA BUNGO \\ J1. Lintas Sumatera Arah Padang KM. 4 Sungai Binjai, Muara Bungo, Provinsi Jambi \\ e-mail: muklisinmukidi@gmail.com
}

\begin{abstract}
Zakat management is an activity of planning, organizing, implementing, and supervising the collection, distribution, and utilization of qakat. Zakat management is carried out by Amil Zakat Agency formed by the government which is organized in the form of an agency or institution. The management system of Amil Zakat Agency (BAZNAS), as a zakat management institution established by the government, is still not optimal and less trusted by the public or muzakeki. This means that the performance still needs to be improved to maintain the continuity of the benefits of the use of zakat and infaq. Therefore, BAZNAS must be able to make a strategy in managing rakat, especially in developing productive businesses so that it can provide and help the productive businesses for citizens so they can develop the economy of their own family.
\end{abstract}

Kata kunci: strategi, manajemen strategi, zakat, usaha produktif

\section{PENDAHULUAN}

$Z$ akat adalah salah satu rukun Islam yang wajib dipenuhi oleh setiap muslim. Menunaikan zakat adalah urusan individu, sebagaimana pemenuhan kewajiban seorang muslim. Apabila seorang mukmin telah beribadah dan melaksanakan kewajibannya di sisi Allah swt dan mendapat ganjaran sebagaimana yang Allah telah janjikan. Zakat dalam pelaksanaannya harus ditetapkan dan diatur oleh agama dan Negara, baik dari segi jenis harta yang dizakatkan, para wajib zakat (muzzaki) maupun para penerima zakat (mustahik), sampai pada pengelolaannya oleh pihak ketiga, dalam hal ini pemerintah atau lembaga yang ditunjuk oleh pemerintah untuk mengelola zakat demi kemaslahatan ummat.

Sebagai Negara dengan jumlah mayoritas muslim, Indonesia sebenarnya tidak hanya mengambil rumusan langkalangkah strategis dari konsep Negara kesejahteraan, melainkan juga dapat merujuk pada konsep dan paradigma kesejahteraan ummat yang ada dalam ajaran Islam. Padahal yang kedua inilah, para pemikir muslim meyakini bahwa didalam prinsip dan ajaran Islam tentang zakat mengandung visi dan misi kesejahteraan masyarakat. Kenyataan sejarah menuturkan bahwa pengelolaan zakat yang dipraktekkan pada masa Rasulullah Saw menjadi bukti yang cukup 
kuat bagi upaya pembentukan Negara dan warga Negara yang bermartabat.

Dalil yang dijadikan dasar hukum bahwa Negara atau pemerintah bertanggungjawab dan berkewajiban dalam mengelola zakat adalah Alqur'an Surat At-Taubah (9): 103,

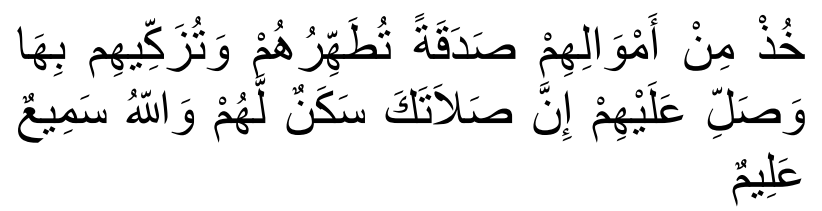

"Ambillah zakat dari sebagian harta mereka, dengan zakat itu kamu membersihkan dan mensucikan mereka dan mendoalah untuk mereka. Sesungguhnya doa kamu itu menjadi ketentraman jiwa bagi mereka, dan Allah swt maha mendengar lagi maha mengetahui" (Q.S. At-taubah [9]: 103).

Manajemen pengelolaan zakat adalah untuk meningkatkan betapa ummat Islam dengan struktur sosial yang sekarang, berikut kemenangan pada kuantitas, tetap saja masih terasa tawar unttuk pengelolaan dana zakat. Hanya sebagian kecil potensi dana zakat yang berhasil dikumpulkan dan didistribusikan kepada yang berhak. Bila melihat pengelolaan dana zakat hanya berlaku sporadik atau kurang terorganisir (Arif Mufraini, 2006: 123 ).

Hasilnya justru pada saat optimalisasi pengelolaan dana diluncurkan lewat UU Nomor. 23 Tahun 2011, isu yang muncul kemudian malah mempertanyakan akan kemampuan sistem zakat sebagai solusi kemiskinan dan pemerataan. Pengumpulan zakat seharusnya merupakan sesuatu yang terprogram dan terencana, termasuk ditentukan jadwalnya dengan jelas, dan tetap berlandaskan untuk beribadah kepada Allah Swt dengan ikhlas. Dalam pengelolaan zakat perlu diperhatikan bahwa pembayaran zakat hendaknya mengetahui kemana harta zakatnya itu disalurkan dan dimanfaatkan. Badan amil zakat harus mempunyai dokumen dan data atau pembukuan yang rinci mengenai jumlah uang zakat yang diterima, orang yang membayarnya, kemana digunakan, dan semacamnya (A. Qodri Azizi, 2004: 144-145).

Ketentuan-ketentuan

hukum mengenai zakat diterapkan dan dikembangkan dengan merumuskan kembali hal-hal yang berhubungan dengan sumber zakat (harta yang wajib dizakatkan) dan pendayagunaan (pendistribusian) zakat, yang ditopang oleh manajemen yang baik, maka peran dan fungsi zakat akan dapat terwujud. Berdasarkan Undang-Undang Nomor 23 Tahun 2011, bahwa organisasi yang berhak mengelola zakat terbagi menjadi dua bagian, yakni organisasi yang tumbuh atas prakarsa masyarakat dan disebut Lembaga Amil Zakat (LAZ) serta organsisai yang dibentuk oleh pemerintah dan disebut dengan Badan Amil Zakat (BAZ). Kedua bentuk organsasi memiliki kesamaan tujuan, yaitu bertujuan mengelola dana zakat dan sumber-sumber dana sosial yang lain secara maksimal untuk keperluan ummat. Misi mulia yang diemban ini jangan sampai berbenturan dalam pelaksanaan programnya (UU No. 23 Tahun 2011 Tentang Pengelolaan Zakat, n.d.).

Di dalam Pasal 1 butir 2 dan 5, pengertian dari zakat adalah harta yang wajib dikeluarkan oleh seorang muslim atau badan usaha untuk diberikan kepada yang berhak menerimanya sesuai dengan syariat Islam. Sedangkan pengertian Muzaki adalah seorang muslim atau 
badan usaha yang berkewajiban menunaikan zakat. Zakat memiliki peranan yang sangat strategis dalam upaya pengentasan kemiskinan atau pengembangan ekonomi. Berbeda dengan sumber keuangan untuk pembangunan yang lain. Zakat harus memiliki mekanisme dan sistem kontrol yang jelas. Hal tersebut bisa dilakukan dengan lembaga terkait. Dengan adanya kewajiban membayar zakat maka orang yang membayar zakat tidak akan pernah habis dan menjadi amal ibadah bagi yang membayarnya.

Pengelolaan zakat adalah suatu kegiatan perencanaan, pengorgansasian, pelaksanaan, pengawasan terhadap pengumpulan dan pendistribusian, serta pendayagunaan zakat. Pengelolaan zakat dilakukan oleh badan amil zakat yang dibentuk oleh pemerintah yang diorganisasikan dalam bentuk suatu badan atau lembaga. Pengumpulan zakat dilakukan oleh badan amil zakat dengan cara menerima atau mengambil dari muzakki atas dasar pemberitahuan dari muzaki (Elsi Kartikasari, 2006: 44).

Badan Amil Zakat (BAZ) sebagai lembaga pengelolaan zakat yang didirikan oleh pemerintah ternyata sistem manajemen pengelolaannya masih belum optimal dan kurang dipercaya masyarakat atau muzakki.Artinya kinerjanya masih perlu ditingkatkan lagi untuk menjaga kesinambungan manfaat penggunaan zakat dan infak tersebut.

Prinsip zakat dalam tatanan sosial ekonomi mempunyai tujuan untuk memberikan pihak tertentu yang membutuhkan untuk menghimpun dirinya selama satu tahun kedepan dan bahkan diharapkan sepanjang hidupnya.
Dalam konteks ini, zakat didistribusikan untuk dapat mengembangkan ekonomi baik melalui keterampilan yang menghasilkan maupun dalam bidang perdagangan. Pendistribusian Zakat bisa melalui pembagian modal usaha kepada para penerima zakat yang dapat digunakan dalam perdagangan (Musyidi, 2006: 171). Target penghimpunan dana zakatnya di BAZNAS Kabupaten Bungo yaitu para pegawai negeri sipil (PNS) yang ada di Kabupaten Bungo. Selain itu lembaga BAZNAS Kabupaten Bungo sendiri juga membuka pintu lebar-lebar untuk para muzaki yang ingin menyalurkan zakatnya walaupun itu orang di luar Kabupaten Bungo.

Problem tentang pengelolaan zakat di BAZNAS Kabupaten Bungo saat ini yaitu terdapat dua hal. Pertama, dari segi sistem pembagian atau pendistribusiannya yang belum optimal. Sebab banyak masyarakat di Kabupaten Bungo yang kurang mampu dan layak menerima zakat sering telat mendapatkan informasi ketika ada pendistribusian zakat. Kedua, dari segi pembagian modal usaha, dimana kondisi saat ini pemberian zakat sebagai modal usaha hanya dilakukan bagi si penerima zakat saja dengan cara masyarakat yang datang langsung ke kantor BAZNAS Kabupaten Bungo kemudian mengajukan proposal usaha kecil. Dari pengajuan tersebut BAZNAS Kabupaten Bungo akan meninjau lagi jenis usaha-usaha yang akan diberikan modal usaha.

Dengan mengamati problematika tentang pengelolaan zakat tersebut diatas, maka dalam hal ini BAZNAS Kabupaten Bungo harus bisa mengatur strategi yaitu dengan menjalin kerjasama antara pihak BAZNAS Kabupaten Bungo dengan pihak 
Pemda Kabupaten Bungo dalam hal pendistribusian zakat, sehingga diharapkan bisa merata kepada masyarakat yang berhak menerima zakat. Selain itu juga pihak BAZNAS Kabupaten Bungo harus mampu menciptakan peluang usaha bagi para mustahik dengan memberikan modal usaha produktif.

Karena itu, strategi pengelolaan dana zakat yang baik akan menciptakan kepercayaan pada masyarakat sehingga masyarakat akan terdorong menyalurkan dananya pada Badan Amil Zakat (BAZ) dari pada menyalurkannya langsung pada mustahik zakat.

Diharapkan dengan adanya lembaga BAZNAS Kabupaten Bungo maka akan mampu meningkatkan perekonomian ummat melalui pemberian dan pemberdayaan zakat melalui program pemberian modal bagi unit usaha kecil menengah. Sehingga unit usaha kecil menengah tersebut juga akan mampu membuka lowongan pekerjaan baru yang dapat mengurangi penganguran di Kabupaten Bungo.

\section{METODE PENELITIAN}

Pada penelitian ini pendekatan yang digunakan adalah menggunakan metode penelitian kualitatif dengan pendekatan deskriptif (deskriptif kualitatif). Dimana dalam pendekatan kualitatif ini sebagai prosedur penelitian yang menghasilkan data deskriptif berupa kata-kata tertulis atau lisan dari orang-orang dan perilaku yang dapat diamati (Nasution, 2003: 9).

Penulis menggunakan penelitian kualitatif karena mempunyai tiga alasan yaitu: Pertama, lebih mudah mengadakan penyesuaian dengan kenyataan yang berdimensi ganda. Kedua, lebih mudah menyajikan secara langsung hakikat hubungan antara peneliti dan subjek penelitian. Dan yang ketiga, memiliki kepekaan dan daya penyesuaian diri dengan banyak pengaruh yang timbul dari pola-pola nilai yang dihadapi. Sedangkan menggunakan pendekatan deskriptif, karena tidak dimaksudkan untuk menguji hipotesis, tetapi hanya menggambarkan suatu gejala atau keadaan yang diteliti secara apa adanya serta diarahkan untuk dapat memaparkan fakta-fakta, kejadian-kejadian secara sistematis dan akurat.

\section{PEMBAHASAN}

\section{Zakat}

\section{Pengertian Zakat}

Ditinjau dari segi bahasa, kata zakat merupakan kata dasar (masdar) dari zaka yang berarti berkah, tumbuh, bersih dan baik. Sesuatu itu zaka, berarti tumbuh dan berkembang dan seorang itu zaka, berarti orang itu baik. Dan bila seseorang diberi sifat zaka dalam arti baik, maka berarti orang itu lebih banyak mempunyai sifat yang baik. Seorang itu zaki, berarti seorang yang lebih banyak sifat-sifat orang baik.

Zakat dari segi istilah fikih berarti "sejumlah harta tertentu yang diwajibkan Allah diserahkan kepada orang-orang yang berhak "disamping berarti "mengeluarkan jumlah tertentu itu sendiri. Jumlah yang dikeluarkan dari kekayaan itu disebut zakat karena yang dikeluarkan itu menambah banyak, membuat lebih berarti dan melindungi kekayaan itu dari kebinasaan (Yusuf Qardhawi, 2004: 34). Adapun zakat 
menurut syarak berarti hak yang wajib (dikeluarkan dari harta).

\section{Syarat-Syarat Wajib Zakat}

a. Milik Sempurna

Yang dimaksud dengan milik sempurna adalah kemampuan pemilik harta mentransaksikan barang miliknya tanpa campur tangan orang lain pada waktu datangnya kewajiban membayar zakat.

b. Berkembang Secara Riil Atau Estimasi

Bahwa harta tersebut harus dapat berkembang secara rill atau secara estimasi. Yang dimaksud dengan pertumbuhan rill adalah pertambahan akibat perkembangbiakan atau per-dagangan. Sedangkan yang dimaksud dengan estimasi adalah harta yang nilainya mempunyai kemungkinan bertambah seperti emas, perak dan mata uang yang semuanya mempunyai kemungkinan pertambahan nilai dengan memperjual belikannya.

c. Sampai Nisab

NiSab adalah sejumlah harta yang mencapai jumlah tertentu yang ditentukan secara hukum, yang mana harta tidak wajib dizakati jika kurang dari ukuran tersebut.

d. Melebihi Kebutuhan Pokok

Harta tersebut merupakan kelebihan dari nafkah dari kebutuhan asasi bagikehidupan muzaki dan orang yang berada dibawah tanggungannya seperti istri, anak, pembantu dan asuhannya.

e. Cukup Haul

Haul adalah perputaran harta satu nisab dalam 12 bulan qomariah (hijriyah). Harta yang wajib zakat tersebut telah dimiliki selama satu haul secara sempurna.

\section{Dasar Hukum Zakat}

Zakat adalah rukun Islam ke tiga yang merupakan pilar agama yang tidak dapat berdiri tanpa pilar. Zakat hukumnya wajib 'ain (fardu 'ain) bagi setiap muslim apabila sudah memenuhi syarat-syarat yang telah ditentukan oleh syariat. Dasar hukum zakat kewajiban mengeluarkan zakat terdapat dalam nash yang shahih, baik dari Alquran maupun dari Hadis.

Diantaranya tercantum dalam surat Al-Baqarah ayat 43 berbunyi:

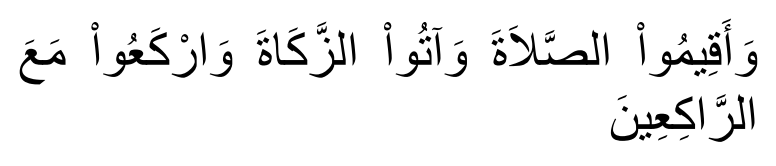

"Dan dirikanlah sholat, tunaikanlah zakat dan rukuklah beserta orang-orang yang rukuk" (Q.S. Al-Baqarah [2]: 43).

Surat Al-Baqarah ayat 277 berbunyi:

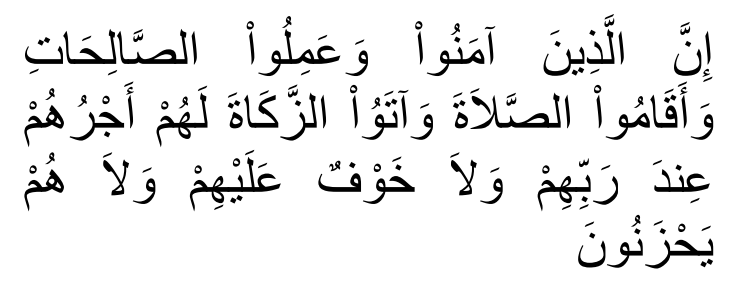

"Sesungguhnya orang-orang yang beriman, mengerjakan amal shaleh, mendirikan shalat dan menunaikan zakat, mereka mendapat pahala disisi Tuhannya. Tidak ada kekhawatiran terhadap mereka dan tidak pula mereka bersedih hati" (Q.S. AlBaqarah [2]: 277).

\section{Prinsip-prinsip Zakat}

Sejalan dengan ketentuan dasar bahwa zakat dapat disebut sebagai pajak kekayaan seseorang, maka dapat ditarik beberapa prinsip yaitu: 
a. Zakat hanya dikenakan pada harta yang mempunyai sifat secara potensial dapat berkembang, baik secara rill berkembangatau tengah disiapkan untuk berkembang, bahkan juga yang tidak dikembangkan ditimbun dalam simpanan.

b. Zakat dibayarkan dari harta yang terkena wajib zakat, jika harta itu merupakan benda bergerak kecuali jika tidak mungkin. Misalnya zakat harta dagangan tidak dibayarkan berupa uang harganya.

c. Zakat dipungut dari harta yang benar-benar hartanya milik dan berada di tangan wajib zakat. Dengan piutang yang berada ditangan debitur tidak wajib dikeluarkan zakatnya oleh pemiliknya sebagai kreditur. Zakat yang tidak dibayarkan pada waktunya tetapi menjadi tanggungan para wajib zakat dan menyangkut semua harta yang terkena wajib zakat.

d. Zakat tetap merupakan kewajiban disamping pajak-pajak yang ditetapkan atas dasar peraturan perundang-undangan Negara. Zakat merupakan kewajiban keagamaan yang hanya dikenakan terhadap harta kekayaan penganut agama Islam. Sedangkan pajak dikenakan terhadap semua penduduk Negara, baik yang beragama Islam maupun yang lainnya.

\section{Hikmah Zakat}

Meskipun zakat hakikatnya adalah kewajiban atas orang kaya untuk memenuhi kebutuhan hak fakir miskin dan lain-lainnya. Namun amat besar pula hikmahnya yang diperoleh para wajib zakat dari adanya kewajiban tersebut. Sesuai dengan arti zakat yang antara lain adalah suci, maka zakat itu diwajibkan dengan tujuan agar dapat menyucikan hati si wajib zakat dari sifat kikir yang merupakan watak pembawaan manusia.

Di antara hikmah zakat adalah:

a. Mensyukuri karunia illahi, menumbuh suburkan harta dan pahala serta membersi hkan diri dari sifat-sifat kikir, dengki, iri serta dosa.

b. Melindungi masyarakat dari bahaya kemiskinan dan akibat kemelaratan.

c. Mewujudkan rasa solidaritas dan kasih sayang antara sesama manusia.

d. Manifestasi semangat kegotong royongan dan tolongmenolong dalam kebaikan dan takwa.

e. Mengurangi kefakir miskinan yang merupakan masalah sosial.

f. Membina dan mengembangkan stabilitas sosial.

g. Salah satu jalan mewujudkan keadilan zakat (Muhammad Daud Ali, 1988: 41).

\section{Manajemen Strategi}

\section{Pengertian Strategi dan Manajemen Strategi}

Kata strategi berasal dari bahasa yunani yang berarti; kepemimpinan dalam ketentaraan. Konotasi ini berlaku selama perang yang kemudian berkembang menjadi manajemen ketentaraan dalam rangka mengelola para tentara bagaimana melakukan mobilisasi pasukan dalam jumlah yang besar, bagaimana mengkoordinasikan komando yang jelas, dan lain 
sebagainya (Crown Dirgantoro, 2001: 5).

Manajemen strategi merupakan kumpulan keputusan dan tindakan yang digunakan dalam menyusun dan mengimplementasikan strategi, yang akan menghasilkan kesesuaian superior yang kompotitif antara organisasi dan lingkungannya, untuk meraih tujuan organisasi (Richard, 2006: 355).

Ada beberapa macam mengenai pengertian manajemen strategi yaitu. Pertama, manajemen strategi adalah proses atau rangkaian kegiatan pengambilan keputusan yang bersifat mendasar dan menyeluruh, disertai penetapan cara melaksanakannya, yang dibuat oleh manajemen puncak dan diimplementasikan oleh seluruh jajaran didalam suatu organisasi untuk mencapai tujuannya.

Kedua, manajemen strategi adalah usaha manajerial menumbuhkan kekuatan organisasi untuk mengeksploitasi peluang yang muncul guna mencapai tujuannya yang telah ditetapkan sesuai dengan misi yang telah ditentukan.

Ketiga, manajemen strategi adalah arus keputusan dan tindakan yang mengarah pada pengembangan suatu strategi atau strategi-strategi yang efektif untuk membantu mencapai tujuan dari organisasi.

Keempat, manajemen strategi adalah perencanaan berskala besar yang berorientasi pada jangkauan masa depan yang jauh, dan ditetapkan sebagai keputusan manajemen puncak agar kemungkinan organisasi berinteraksi secara efektif (Hadari Nawawi, 2000: 148).
2. Tahapan Manajemen Strategi

Tahapan tahapan yang dilalui dalam proses manajemen strategis yaitu:

a. Perumusan misi organisasi

b. Penentuan profil organisasi

c. Analisis dan pilihan strategi

d. Penentuan strategi induk

e. Penentuan strategi operasional

f. Perumusan kebijaksanaan

g. Penciptaan sistem pengawasan

h. Penciptaan sistem umpan balik (Crown Dirgantoro, 2001: 20).

\section{Strategi Pengelolaan Zakat oleh BAZNAS Kabupaten Bungo}

Dalam hal ini lembaga amil zakat Nasional (BAZNAS) tingkat Kabupaten harus bisa menciptakan suatu strategi sebagai dasar referensi dalam sebuah organisasi yang professional. Professional dalam mengatur segala bidang mulai dari anggaran, sistem, pengukuran, kinerja, penerapan sasaran, pemilihan jenis usaha, program kerja para amil zakat dan lainnya.

Dengan fokus pada strategi maka BAZNAS Kabupaten Bungo diharapkan mampu menyelamatkan dirinya agar eksis dalam mendayagunakan dana masyarakat di masa depan.

Kabupaten Bungo yang terletak di provinsi Jambi dalam pengelolaan zakat mempunyai Strategi yang diharapkan akan mampu memberikan kontribusi dalam pemberdayaan ekonomi ummat khususnya pada masyarakat kabupaten Bungo dan sekitarnya. 
Ada beberapa strategi dalam pengelolaan zakat yang dilakukan oleh BAZNAS Kabupaten Bungo sehingga diharapkan mampu meningkatkan kepercayaan para muzaki, yaitu sebagai berikut:

\section{Pengenalan Masalah}

Dalam menanggulangi permasalahan sosial disuatu tempat, yang harus dilakukan terlebih dahulu adalah mengenali suatu persoalan. Solusi tidak akan berguna jika persoalan tidak dikenali terlebih dahulu. Persoalan akan muncul karena adanya penyebab dan penyebab akan mengakibatkan dampak. Permasalahan sosial yang umumnya sangat mencolok di daerah khususnya di Kabupaten Bungo adalah dalam hal kesenjangan sosial. Dimana antara masyarakat miskin dengan kaya terdapat perbedaan golongan, seperti golongan kelas bawah dan golongan menengah keatas.

Sebagai lembaga amil zakat BAZNAS Kabupaten Bungo dalam mencari permasalahan yang timbul dalam pengelolaan zakat dan pendistribusiannya maka bisa dengan melakukan evaluasi terhadap kasus-kasus yang telah terjadi pada tahun-tahun sebelumnya. Setelah melakukan evaluasi maka diharapkan kasus-kasus permasalahan zakat tidak akan terulang kembali. Dengan kata lain BAZNAS Kabupaten Bungo harus pandai belajar dari pengalamanpengalaman yang telah lalu.

\section{Penciptaan Peluang Usaha Bagi Para Mustahik}

Menciptakan peluang usaha bagi para mustahik membutuhkan analisis keputusan yang tepat. Dengan analisis ini, maka di harapkan BAZNAS Kabupaten Bungo dapat menentukan skala prioritas mana yang memiliki tingkat kemaslahatan yang penting.

Cara yang dilakukan oleh BAZNAS Kabupaten Bungo dalam menciptakan peluang usaha yaitu pihak BAZNAS Kabupaten Bungo memberikan bantuan berupa modal usaha kepada para mustahik zakat.

Dengan adanya peluang usaha bagi para mustahik maka diharapkan mampu mengembangkan usaha kecil menengah dengan modal berasal dari zakat akan menyerap tenaga kerja. Contoh usaha kecil menengah yaitu seperti usaha idustri rumahan yang ada di Kabupaten Bungo di Dusun Purwabakti berupa pengolahan pisang menjadi pisang sale, kripik pisang, kripik tempe, kripik ubi, dan lain-lain.

Jenis usaha yang lain yang diberikan bantuan modal usaha oleh pihak BAZNAS Kabupaten Bungo dalam bentuk bantuan Gerobak kaki tiga untuk usaha seperti berjualan sarapan pagi seperti Lontong, Nasi gemuk, jual manisan, jual pulsa dan lain-lain.

Kegiatan BAZNAS Kabupaten Bungo ini patut dicontoh dan diikuti karena juga dapat mengurangi pengangguran khsususnya di Kabupaten Bungo berkat bantuan dari pihak BAZNAS Kabupaten Bungo.

\section{Mengembangkan Usaha Produktif}

Dengan adanya BAZNAS Kabupaten Bungo maka diharapkan mampu menyediakan atau membantu usaha produktif bagi masyarakat sehingga 
mereka dapat mengembangkan ekonomi keluarga mereka sendiri.

Kegiatan industri kecil di Kabupaten Bungo dapat berpotensi menyerap banyak tenaga kerja yang meliputi pengelolaan barang produksi, pengelolaan limbah, pemanfaatan sumber daya alam, dan pendistribusiannya.

Hal ini oleh pihak BAZNAS Kabupaten Bungo dapat dijadikan kebijakan yang ditujukan untuk mencapai sasaran pembangunan, yakni meningkatkan produktivitas masyarakat kecil meningkatnya lapangan kerja, dan terciptanya semangat pembentukan iklim sumber daya manusia yang kreatif. Dan secara tidak langsung juga dapat membantu kinerja pemerintahan daerah kabupaten Bungo.

\section{Membuat Jaringan Pengusaha Kecil}

Pembuatan jaringan pengusaha kecil sangat baik bagi terciptanya kestabilan dalam usaha. Dalam hal ini industri kecil berbasis syariah harus bisa solid bila tidak ingin tergilas oleh zaman. Yang perlu dihadirkan adalah asosiasi ekonomi industri kecil yang berbasis syariah.

Dalam hal ini BAZNAS Kabupaten Bungo baru merintis membuat jaringan pengusaha kecil dengan cara mendata dan mengumpulkan para pengusaha kecil sesuai dengan bidang usahanya masing-masing. Secara khusus memang belum terkoordinir dengan baik akan tetapi ada juga berupa Koperasi syariah, namun di Kabupaten Bungo belum maksimal dalam pengelolaannya.
Sebenarnya dengan adanya jaringan pengusaha kecil tersebut diharapakan akan mampu berperan dalam mengokohkan ikatan para pengusaha kecil, baik dalam bentuk jaringan bisnis advokasi, maupun pertukaran informasi antar lembaga terkait.

\section{Memanfaatkan Peran Bappeda Daerah}

Selaras dengan semangat otonomi daerah, maka desentralisasi untuk mengembangkan industri kecil akan berhasil bila dibarengi dengan penguatan peran serta masyarakat. Badan Perencana Daerah (BAPPEDA) Kabupaten Bungo harus menciptakan perencanaan strategis bagi berkembangnya bisnis sektor ini. Apalagi Kabupaten Bungo adalah kota Lintas yang selalu ramai dilalui oleh kabupaten lainnya dan merupakan kota yang baru berkembang. Dalam hal ini BAZNAS Kabupaten Bungo harus bisa merangkul dan bekerjasama dengan BAPPEDA daerah untuk membicarakan soal terkait kontribusi zakat, sedekah, dan dana-dana sosial lainnya yang dapat dialokasikan untuk pemberdayaan ekonomi ummat, khususnya masyarakat Kabupaten Bungo sendiri.

\section{PENUTUP}

\section{Kesimpulan}

Pengelolaan zakat adalah suatu kegiatan perencanaan, pengorgansasian, pelaksanaan, pengawasan terhadap pengumpulan dan pendistribusian, serta pendayagunaan zakat. Pengelolaan zakat dilakukan oleh badan amil zakat yang 
dibentuk oleh pemerintah yang diorganisasikan dalam bentuk suatu badan atau lembaga.

Dalam hal ini terkait pengelolaan zakat Badan Amil Zakat Nasional (BAZNAS) di Kabupaten Bungo membuat strategi pengelolaan dan pengembangan zakat yaitu:

1. Pengenalan masalah

2. Penciptaan peluang usaha bagi para mustahik

3. Mengembangkan usaha produktif

4. Membuat jaringan pengusaha kecil

5. Memanfaatkan peran Bappeda

\section{Saran}

Beberapa hal yang disarankan sebagai berikut:

1. Perlu dibentuk adanya Badan Amil Zakat Nasional (BAZNAS) di Kabupaten Bungo untuk pengelolaan dan pemberdayaan zakat di Kabupaten Bungo sehingga dapat meningkatkan perekonomian ummat.

2. Diperlukan kesadaran para mustahik zakat untuk mau menunaikan kewajiban zakat.

3. BAZNAS Kabupaten Bungo harus bisa mengembangkan usaha produktif yang mampu memberikan kontribusi kepada golongan bawah (miskin).

4. Perlunya kerjasama antara BAZNAS dan BAPPEDA Kabupaten Bungo yang saling merangkul dan bekerjasama untuk membicarakan soal-soal terkait kontribusi zakat, pengelolaan zakat, sedekah, dan dana-dana sosial lainnya yang dapat dialokasikan untuk pemberdayaan ekonomi ummat.

\section{DAFTAR KEPUSTAKAAN}

Ali, Muhammad Daud. 1988. Sistem Ekonomi Islam Zakat Dan Wakaf. Jakarta: UI Press.

Azizi, A. Qodri. 2004. Membangun Fondasi Ekonomi Umat. Yogyakarta: Pustaka Pelajar, Cetakan 1.

Dirgantoro, Crown. 2001. Manajemen Stratejik Konsep, Kasus dan Implementasi. Jakarta: Grasindo.

Kartikasari, Elsi. 2006. Pengantar Hukum Zakat dan Wakaf. Jakarta: Penerbit Cikal Sakti.

Mufraini, Arif. 2006. Akuntansi Dan Manajemen Zakat; Mengomunikasikan Kesadaran Dan Membangun Jaringan. Jakarta: Kencana Prenada Media Group.

Musyidi. 2006. Akuntansi Zakat Kontemporer. Bandung: Remaja Rosdakarya.

Nasution. 2003. Metode Research. Jakarta: PT. Bumi Aksara.

Nawawi, Hadari. 2000. Manajemen Sumber Daya Manusia untuk Bisnis yang Kompetitif. Yogyakarta: Gajah Mada University Press.

Qardhawi, Yusuf. 2004. Hukum Zakat, Studi Komparatif Mengenai Status Dan Filsafat Zakat Berdasarkan Quran Dan Hadist. Jakarta: Pustaka Litera Antarnusa

Richard. 2006. Manajemen. Jakarta: Salemba Empat, Edisi 6.

UU No. 23 Tahun 2011 Tentang Pengelolaan Zakat. 